\title{
THALLIUM TOXICITY IN HUMANS
}

\author{
Petra CVJETKO ${ }^{1}$, Ivan CVJETKO ${ }^{2}$, and Mirjana PAVLICA ${ }^{1}$ \\ Department of Molecular Biology, Faculty of Science, University of Zagreb ${ }^{1}$, University Hospital Merkur, Medical \\ School, University of Zagreb ${ }^{2}$, Zagreb, Croatia \\ Received in May 2009 \\ Accepted in November 2009
}

\begin{abstract}
Thallium is a naturally occurring trace element, widely distributed in the earth's crust, but at very low concentrations. It does not have a known biological use and does not appear to be an essential element for life. It has been considered one of the most toxic heavy metals.

Occasionally, there are reports on thallium poisoning as results of suicide or murder attempt or accident. The main threat to humans is through occupational exposure, environmental contamination, and accumulation in food, mainly in vegetables grown on contaminated soil. Increasing use in emerging new technologies and demanding high-tech industry constantly raise concern about exposure risk to all living organisms. Thallium is considered a cumulative poison that can cause adverse health effects and degenerative changes in many organs. The effects are the most severe in the nervous system. The exact mechanism of thallium toxicity still remains unknown, although impaired glutathione metabolism, oxidative stress, and disruption of potassium-regulated homeostasis may play a role. The lack of data about mutagenic, carcinogenic, or teratogenic effects of thallium compounds in humans calls for further research.
\end{abstract}

KEY WORDS: alopecia, environmental contamination, heavy metals, neuropathy, peripheral, poisoning

Thallium (Tl) is an extremely toxic metal. However, it has not been studied extensively and published toxicity studies are few. One of the reasons may be that classical analytical methods have poor sensitivity to thallium (1). Preconcentration procedure, selective separation, and purification methods are often needed for thallium determination when its concentration is too low to be determined (2). This has pointed out the need for development of a highly sensitive and reliable method, one that would be able to determine ultratrace thallium levels (3).

Currently used methods include molecular spectrophotometry and spectrofluorimetry, mass spectrometry (MS), atomic absorption spectrometry (AAS), voltammetry, neutron activation analysis (NAA), X-ray fluorimetry, inductively coupled plasma (ICP) techniques, differential pulse anodic stripping voltammetry (DPASV), and graphite furnace atomic emission spectrometry (GFAAS) (2-4).
Thallium is included in US Environmental Protection Agency list of priority toxic pollutants as it has caused a number of accidental and occupational poisonings. Thallium toxicity has not been studied extensively in all living organism because it has already been established that this metal is extremely toxic. For this reason the Commission of the European Communities finds that there is no need for further investigation. However, for the lack of experimental animal, epidemiological, mutagenicity, and genotoxicity data, the Commission could not classify thallium with respect to its (potential) carcinogenicity (5).

The Health Council of the Netherlands and its Committee on Updating of Occupational Exposure Limits for thallium compounds, who had reviewed the original publications until 1998 and studied new literature in 1999 and 2002, found no additional information that would affect the previous Commission conclusions (6). 
On the other hand, the rising impact of anthropogenic sources of contamination indicates that thallium is still underestimated and understudied. Studies of Canadian rivers and lakes downstream of coal mines and coal-fired power stations showed elevated thallium concentrations $(7,8)$. Another study of thallium, cadmium, and lead atmospheric deposition in Greenland ice core indicated that coal burning in North America and Europe was the source of these metals in the Arctic by the early 1900s, to the extent of two to five times higher deposition than during recent decades. Although these results show substantially lower heavy-metal pollution in the North Atlantic sector of the Arctic than a century ago, contamination of other sectors may be increasing because of the rapid coal-driven growth of Asian economies (9).

Thallium concentrations in surface and underground water might be higher than naturally occurring. Lin and Nriagu (10) believe that the distribution of thallium in two US rivers points to urban run-off as an important contamination source.

\section{PHYSICAL AND CHEMICAL PROPERTIES OF THALLIUM}

Two scientists, William Crookes and ClaudeAuguste Lamy independently discovered thallium by flame spectroscopy (11). At that time, this was a new improved method to make spectroscopic determinations of minerals. In 1861, Crookes was trying to extract selenium from sludge left over from the production of sulphuric acid. He noticed a new green line in the spectrum and concluded that this was a new element, which he named "thallium" from Greek $\theta \alpha \lambda \lambda o ́ s$, thallos, a green shoot or twig. Only a year later, Lamy had independently isolated thallium and continued to study its chemical and physical properties. The controversy between the two scientists lasted a while because both claimed to have been the first to discover this new element.

Thallium is considered a heavy metal on account of its density $\left(11.83 \mathrm{~g} \mathrm{~cm}^{-3}\right)$. In its pure form, thallium is bluish-white in colour and very soft and malleable. It melts at $303.5^{\circ} \mathrm{C}$ and boils at $1482{ }^{\circ} \mathrm{C}$. Thallium salts are tasteless, odourless, and colourless. It is a very reactive metal. When exposed to air and moisture, it oxidises at the surface, forming a coating of $\mathrm{Tl}(\mathrm{I})$ oxide $\left(\mathrm{Tl}_{2} \mathrm{O}\right)$. At higher temperatures it forms $\mathrm{Tl}(\mathrm{III})$ oxide $\left(\mathrm{Tl}_{2} \mathrm{O}_{3}\right)(12)$.
Thallium has 47 isotopes, with atomic masses ranging from $179 \mathrm{u}$ to $210 \mathrm{u}$. The half-life of the unstable isotopes ranges from 0.06 years to 3.78 years (6). ${ }^{204} \mathrm{Tl}$ is the most stable radioisotope, with a half-life of 3.78 years. Natural thallium is a mixture of two stable isotopes, ${ }^{205} \mathrm{Tl}(70.5 \%)$ and ${ }^{203} \mathrm{Tl}(29.5 \%)$, and has an atomic mass of $204.38 \mathrm{u}$. This mass may vary about $2 \%$, depending on isotope composition in various natural materials, particularly seawater and sedimentary rocks (13).

Thallium appears as monovalent thallo- and trivalent thalli-compound. It tends to form stable complexes such as sulphur-containing compounds. The chemical properties of the monovalent compound are similar to alkali metals whereas the trivalent compound behaves more like aluminium. As a nonessential element, it plays no role in human, plant, or animal metabolism.

\section{NATURAL SOURCES}

Thallium is widely distributed in the earth's crust in the form of salts and minerals, usually at concentrations ranging from $0.3 \mathrm{mg} \mathrm{kg}^{-1}$ to $0.6 \mathrm{mg} \mathrm{kg}^{-1}$ (14). In the oceanic crust, this concentration drops to $0.013 \mathrm{mg} \mathrm{kg}^{-1}$ (15). Thallium is estimated to have a mean seawater concentration of $65 \mathrm{pmol} \mathrm{kg}^{-1}$ (13). The main oceanic sources of dissolved thallium are rivers, thermal waters, volcanic gasses, mineral aerosols, and benthic fluxes from continental margin sediments. Cosmic dust, although insignificant compared to other fluxes, is another potential source of dissolved oceanic thallium with a maximum concentration of $150 \mathrm{ng} \mathrm{g}^{-1}(13)$.

In the world there are a few areas with naturally high thallium concentrations such as the southwestern Guizhou Province in China (16), Allchar mine in Kavadarci, Macedonia (17), Lengenbach in Switzerland (18), and Rotokawa in New Zealand (19).

Thallium behaviour in weathering processes is relatively little known. Thallium is easily released during weathering and transported with alkaline metals, but its great ionic radius causes it to quickly bond to ferric or manganese oxides, clay minerals, and some gels (20). Weathering can lead to erosion and natural contamination of soil. Several studies of population inhabiting some of the above mentioned naturally thallium-rich areas have confirmed increased thallium exposure through food grown in these areas (16). 
In nature, thallium is present as a trace compound in many minerals, mainly associated with potassium, copper, gold, zinc, and rubidium. Naturally occurring minerals with higher thallium concentration include crooksite, found in Sweden and Brazil, lorandite (Greece and the USA), hutchinsonite (Switzerland), orabite (Brazil and the USA), and berzelianite (Germany) (15). Several of these thallium minerals contain $16 \%$ to $60 \%$ of thallium, but have no commercial importance as a source of this element. The major sources of commercial thallium are copper, lead, zinc, and other sulphide ores (21).

Thallium concentration in soil correlates with geological composition. Sulphide ores are usually accompanied by higher thallium content. An example is the Kuroko-type volcanogenic sulphide ore, which contains significant thallium levels, mainly in the form of pyrite (22).

Although the geochemistry of thallium is known quite well, its behaviour in geological processes and its cycle from the lithosphere to the hydrosphere and biosphere is still unclear (12).

\section{SAFETY GUIDELINES}

Because of thallium's potential to cause adverse health effects in exposed people, a number of regulations and guidelines have been established by national and international agencies, including World Health Organization (WHO), US Environmental Protection Agency (US EPA) and European Health Committee (CDSP). Threshold limits and other safety standards are important in occupational medicine and environmental control to prevent health risks.

The maximum contaminant level (MCL) for thallium in drinking water, at which no known adverse effects on human health are anticipated, is $0.002 \mathrm{mg}$ $\mathrm{L}^{-1}$. According to US EPA, MCL is the lowest level at which water suppliers can reasonably be required to remove the contaminant of interest, should it occur in drinking water $(23,24)$.

There is another non-regulatory, health-based chemical concentration for contaminants in drinking water called the health advisory level (HAL), which defines contaminant concentration resulting in no adverse health effects when a given amount of water is ingested over exposure periods ranging from one day to a lifetime. This level for a child exposed to thallium is $0.007 \mathrm{mg} \mathrm{L}^{-1}(23)$.

The Office of Environmental Health Hazard Assessment (OEHHA) has developed a Public Health
Goal (PHG) of $0.1 \mu \mathrm{g} \mathrm{L}^{-1}$ for thallium in drinking water. This level in drinking water indicates estimated concentration that would pose no significant health risk to individuals consuming water on a daily basis over a lifetime (25).

The generally accepted limit for thallium content in arable soil is $1 \mathrm{mg} \mathrm{kg}^{-1}$ (26). Worldwide limits for crops and land plants are $0.03 \mathrm{mg} \mathrm{kg}^{-1}$ to $0.3 \mathrm{mg} \mathrm{kg}^{-1}$ (dry mass) and $8.0 \mu \mathrm{g} \mathrm{kg}^{-1}$ to $1 \mathrm{mg} \mathrm{kg}^{-1}$ (dry mass), respectively (20).

\section{USES}

In the last century, thallium was very popular as a medical agent for treating heavy persistent night sweats or ringworm, and a depilatory agent. It was widely used as a rodenticide and an insecticide but because of multiple cases of unintentional poisoning, household use was soon banned. An exception are underdeveloped countries where thallium is still in use. The WHO recommendation against its use dates from 1973 (27).

Before the world became aware of its severe toxicity, thallium was also used to treat sexually transmitted diseases such as syphilis and gonorrhoea. It is due to indiscriminate therapeutic use that the first thallium-induced toxic symptoms were described in the neuromuscular and gastrointestinal system. Since its introduction in medicine, toxic consequences were constantly reported. Thallium is still applied in clinical diagnostics as a contrast agent for cardiovascular and tumour imaging (21).

Industrial use of thallium is very extensive, mostly in specialised electronic equipment. Most gamma radiation detection equipment such as scintillometer and infrared radiation detection and transmission equipment contains thallium as an activator (28). Thallium-barium-calcium-copper oxide high-temperature superconductors (HTS) are used in filters for wireless communications. This use in particular threatens to increase the demand for thallium because at the moment, thallium materials are superior and more cost-effective for these very specialised uses (28). Thallium-arsenic-selenium crystals are essential in filters for light diffraction in acousto-optic measuring devices. Thallium is used in an alloy with mercury to measure low temperatures (26-28). Other uses include an additive in glass to increase its refractive index and density, a catalyst or intermediate in the synthesis of organic compounds, 
and a component in high-density liquids for sink-float separation of minerals.

Man-made sources of thallium pollution are gaseous emissions from cement factories, coal burning power plants, and metal sewers. Leaching of thallium from ore processing operations is the major source of elevated thallium concentrations in water. Major industrial sources of elevated thallium include primary copper smelting, petroleum refining, primary nonferrous metals, blast furnaces, and steelworks (24).

According to estimations by the US Geological Survey (USGS) based on thallium content in zinc ores, world resources of thallium are around 17,000 t. Additional 630,000 $\mathrm{t}$ are in the world coal resources (28). The world annual production of thallium has remained fairly constant; $12 \mathrm{t}$ in 2004 and $10 \mathrm{t}$ from 2005 to now (28-30). The price of thallium has increased over the recent years, as the supply worldwide had continued to be relatively tight. In 2008 the price increased about $7 \%$. Overall, it tripled from 2005 to 2008 (30).

Research and development activities in 2008 have further increased the use of thallium. A newly invented thermoelectrical material containing thallium could make automobiles more efficient. Because $60 \%$ of the energy produced by a typical gasoline engine is lost through waste heat, the use of a new thalliumdoped lead telluride instead of the currently used commercial sodium-doped lead telluride could more than double heat conversion into electrical energy (30). The application of this material could be extended to power generators and heat pumps as well.

\section{MECHANISM OF TOXICITY}

The exact mechanisms that mediate thallium toxicity are still poorly understood and not known since thallium interacts with cells at different levels. Thallium can mimic potassium ion in most biological processes because of the same ionic radius and inability of the cell membrane to differentiate between this two cations. Moreover, thallium follows potassium distribution pathways and in this way alters many of potassium-dependent processes. For example, thallium may substitute potassium in the $\mathrm{Na}^{+} / \mathrm{K}^{+}$-ATPase. Interference with potassium transport has been demonstrated in rabbits, where thallium had a 10 times higher affinity for $\mathrm{Na}^{+} / \mathrm{K}^{+}$-ATPase than potassium (31).
Another possible mechanism of toxicity is thallium's capacity to react with thiol groups (32). Thallium seems to inhibit a range of enzyme reactions and to interfere with a variety of vital metabolic processes, disrupting cell equilibrium, which in turn leads to generalised poisoning (33). Due to the presence of empty d-orbitals in electronic configuration, thallium has a high affinity for sulphur ligands. It can form complexes with and thus inactivate sulphhydryl groups of proteins which are usually involved in reactions catalysed by enzymes (34). Inhibition of enzymes with active sites containing cysteine residues may increase oxidative stress as a result of glutathione modification (34).

When bound to membrane phospholipids, especially to the anionic headgroups, thallium changes membrane rheology, lipid packing, lipid arrangement in the lateral phase of the bi-layer, and the hydration of the polar headgroups (35). This in turn could affect the activity of membrane-associated enzymes, intracellular transport, and the function of receptors that could contribute to the neurotoxicity associated with thallium poisoning (36).

Some evidence implies that thallium triggers oxidative stress in the cell. In fact, thallium deposits in the brain and a local increase in lipid oxidation products have been reported in rats poisoned with thallium $(37,38)$. Moreover, the ability of thallium to oxidise membrane lipids and alter their fluidity, could ultimately disrupt membrane-associated metabolic processes (38).

Thallium affects the metabolism of glutathione, a non-protein thiol whose major role is to maintain plasma oxidant homeostasis by defending against reactive oxygen species. In addition, glutathione plays a crucial role in heavy metal toxicity by binding heavy metals through its SH group, which ends in their excretion. The impairment of this protective system can result in the accumulation of oxidant species, that could adversely affect different molecules and their related cellular processes (39). Hanzel et al. (36) investigated the effects of thallium (III) hydroxide on glutathione metabolism in vitro using rat brain cytosolic fractions. Thallium hydroxide decreased inhibited glutathione peroxidase and glutathione reductase activity (38).

Thallium may also exert toxicity by disturbing the mitochondrial function. In millimolar concentrations, it affected the function of isolated mitochondria by opening the transition pores and by uncoupling of the respiratory chain $(40,41)$. It also caused swelling 
of isolated mitochondria and increased oxygen consumption and lactic acid production in tumour cells in vitro (32).

At present, no data are available about mutagenic, carcinogenic, or teratogenic effects of thallium compounds in humans. Without this information, no dose-response assessment can be made.

\section{HUMAN STUDIES}

Thallium is considered a cumulative poison. Numerous studies indicate that thallium compounds are readily absorbed in humans and animals. Human exposure may take different routes: oral, by ingestion of contaminated food, dermal, or respiratory, by inhalation of dust and fumes. Once it enters the body, the severity of intoxication will depend on the quantity of thallium absorbed, immune reaction, and individual tolerance of the poison (42).

Absorption of thallium by mucosa is almost complete $(80 \%$ to $100 \%)$ and very quick. After absorption thallium is distributed from blood to tissue (6). In humans, kidneys display the highest concentrations, followed, in a decreasing order, by the bones, stomach, intestines, spleen, liver, muscle, lung, and brain (15).

It is well documented that thallium crosses the placental barrier and is excreted in breast milk (43). Thallium can also cross the blood-brain barrier $(44,45)$ and deposit in the brain, where it causes neurodegeneration, demyelination, and the accumulation of end products of lipid oxidation.

Thallium is excreted through sweat, saliva, and tears (32). Deposition in the hair and nails is also an important route of thallium elimination. Generally, elevated levels in the urine, blood, and saliva are better indicators of poisoning than thallium content in the hair, since elevated hair content can be exogenous, and may have to do with thallium-containing dust in hair (12).

Routes of thallium excretion in humans include renal and faecal. The relative contribution depends on the status of the patient, dosage, quantity of potassium present, and the time of measurement (6).

Due to its large distribution volume (term used to quantify the distribution of thallium between plasma and the rest of the body), thallium is released slowly from the body. Residues of thallium can be detected for months following exposure. The slow rate of excretion enables its accumulation even at low levels of exposure. The biological half-life in humans has been estimated to about 10 days, but up to 30 days has been reported (32).

The minimum lethal dose of soluble thallium salts has been estimated to $0.7 \mathrm{~g}$ to $1.1 \mathrm{~g}$ for adults with a body mass of $70 \mathrm{~kg}$ or $10 \mathrm{mg} \mathrm{kg}^{-1}$ to $15 \mathrm{mg} \mathrm{kg}^{-1}$ of body mass (46). Studies assessing human exposure to thallium through food, vegetables in particular, in a wide variety of geographic locations speak about $<2 \mu \mathrm{g} \mathrm{d}^{-1}$ in average as indicted by Sabbioni et al. (47). A correlation between thallium content in the environment and cardiovascular diseases has also been established (12).

Symptoms of thallium poisoning are diverse and nonspecific. Due to complex multi-organ involvement, including the heart, kidneys, nervous and gastrointestinal system, accurate diagnosis is often delayed. Clinical manifestations of thallium poisoning can be classified as acute, subchronic, and chronic, depending on the level of toxin, severity, and time of exposure. The most prominent feature of thallium poisoning is the loss of hair or alopecia. Other symptoms such as gastrointestinal disturbances, high blood pressure, tachycardia, and persistent weakness, are not specific for thallium alone (12).

Acute thallium poisoning is usually accompanied by gastrointestinal symptoms, while neurological findings (sensory and motor changes) predominate in chronic exposure. Other symptoms include polyneuritis, encephalopathy, tachycardia, degenerative changes of the heart, liver, and kidney, subarchanoid haemorrhage, and bone marrow depression (48). Gastrointestinal symptoms usually appear within the first few hours of acute poisoning. Severe abdominal pain goes along with vomiting, nausea, and bloody diarrhoea. In contrast, these symptoms are mild or nonexistent in chronic exposure.

Irrespective of the route of entry, progressive peripheral neuropathies develop into severe painful sensations two to five days after exposure. Kuo et al. (49) reported development of paraesthesia of the hand and lower limbs, especially of the soles, as well as distal motor weakness and sensory impairment. Thallium poisoning can sometimes be misdiagnosed as Guillain-Barré syndrome (GBS) because of the development of neuropathy with symptoms characteristic for this disease (50). These symptoms include muscle weakness, paraesthesia, and hyporeflexia.

Nerve conduction studies confirmed axonal degeneration and decreased fibre density in large 
myelinated fibers in patients with acute thallium poisoning (49). Even though these symptoms are not specific, if accompanied by alopecia and behavioural abnormalities, they can be a clue for diagnosing thallium poisoning. Highly suggestive signs of thallium poisoning are also ophtalmoplegia and cerebellar and extrapyramidal motor disturbances (50).

Thallium poisoning can also be associated with neuropsychological symptoms and psychosis as signs of personality changes such as depression, apathy, anxiety, confusion, delirium, and hallucinations.

Immediate cardiovascular complications manifest as severe tachycardia, hypertension, ventricular fibrillation, and other ECG abnormalities $(34,50)$.

In many cases, abnormal colour vision and impaired visual acuity may develop. Toxic optic neuropathy can lead to the atrophy of the optic nerve, ophtalmoplegia, and nystagmus.

The first dermatologic symptoms are not specific and appear as scaling of the palms and soles. Acneiform lesions of the face burst out. Hair loss occurs after two to three weeks and is sometimes accompanied by loss of eyebrows and eyelashes.

Some authors suggest that thallium's affinity for sulphhydryl groups may be responsible for alopecia; thallium prevents keratinisation of hair proteins by binding with cysteine. Skin biopsies taken from patients with alopecia and other symptoms of thallium poisoning revealed atrophic and necrotic changes of the skin such as parakeratosis, dilated hair follicles filled with keratin and necrotic sebaceous materials, mild epidermal atrophy, and vacuolar degeneration of the basal layer (49-52).

About one month after poisoning, transverse white lines called Mee's lines appear in the nail plate as results of complete erosion of the proximal parts of nails following thallium poisoning (53).

In the most severe cases ataxia, tremor, headache, seizure, and insomnia precede coma and death.

An extensive literature review (43) demonstrated a range of foetal effects, from severe toxicity with residual sequelae to outwardly normal development. Interestingly, some newborns appeared normal despite severe maternal poisoning. The only consistent effect was a trend toward prematurity and low birth weight in children exposed during early gestation.

\section{DETOXICATION}

Lack of symptoms, or at least any unexplained peripheral neuropathy accompanied by alopecia should always raise clinical suspicion for thallium toxicity. As mentioned above, early symptoms often do not point to thallium poisoning and postpone accurate diagnosis. Therefore, appropriate therapeutic measures should be initiated as soon as possible, while laboratory confirmation is still pending. If recognised and treated early, the prognosis is good.

Taking into account that thallium is one of the most toxic heavy metals and that its concentration must be established quickly, the techniques for selective thallium detection and determination in biological samples has been proposed by Das et al. (4). The standard toxicological method relies on 24-hour urine thallium concentration determined by atomic absorption spectrometry.

In the first couple of hours after thallium poisoning, the patient receives gastric lavage and is induced emesis in order to prevent further absorption of thallium into the body. Haemodialysis is also recommended to prevent further thallium distribution through blood. To minimise the effect on the liver (54), charcoal can be used. Additionally, treatment with potassium chloride may promote renal excretion of thallium.

For years, ferric hexacyanoferrate, $\left(\mathrm{Fe}_{4}\left[\mathrm{Fe}(\mathrm{CN})_{6}\right]_{3}\right)$ has been the most common antidote for thallium poisoning. This compound is also known as also known as Prussian blue, iron blue, Chinese blue, Paris blue, Brunswick blue, and Turnbull's blue (55, 56) and in addition to serving as industrial and art painting pigment, it is used to interrupt re-adsorption of thallium in the intestine and increase its elimination from the body.

Since thallium is radiopaque, abdominal radiograph may be useful for confirming its presence.

Nerve conduction studies have revealed abnormalities consistent with peripheral neuropathy and neurological tests may be useful in both diagnosing and monitoring exposed patients (53). Electroretinographic (ERG) examination may also help in early diagnosis, as it reveals delayed visual evoked response that tends to occur before the development of clinical symptoms in thallium poisoning (57).

\section{CONCLUSION}

Thallium can reasonably be expected to pose a threat to the environment, mainly because of anthropogenic activities. Natural inputs of thallium are not considered toxicologically significant. As thallium 
is no more commercially available for domestic use, the most severe poisonings are related to murder or suicide attempts and accidental occupational exposure.

The exact mechanism of thallium toxicity still remains unknown, although impaired glutathione metabolism, oxidative stress, and disruption of potassium-regulated homeostasis may play a role. The lack of data about mutagenic, carcinogenic, or teratogenic effects of thallium compounds in humans calls for further research of this very toxic heavy metal.

\section{REFERENCES}

1. John Peter AL, Viraraghavan T. Thallium: a review of public health and environmental concerns. Environ Int 2005;31:493501.

2. Das AK, Dutta M, Cervera ML, de la Guardia M. Determination of thallium in water samples. Microchem J 2007;86:2-8

3. Saha A. Thallium toxicity: A growing concern. Indian J Occup Environ Med 2005;9:53-6.

4. Das AK, Chakraborty R, Cervera ML, Guardia MDI Determination of thallium in biological samples. Anal Bioanal Chem 2006;385:665-70.

5. Thallium; thallium metal; thallium(III) oxide; thallium sulfate. In: Aresini G, Draper MH, Duffus JH, van der Venne M, editors. The toxicology of chemicals - Series 1 . Carcinogenicity. Vol IV - Summary review of the scientific evidence. Luxembourg: Commission of the European Communities; 1993. p. 129-39.

6. Health-based Reassessment of Administrative Occupational Exposure Limits - Thallium and water-soluble thallium compounds [displayed 28 July 2009]. Available at http:// www.gezondheidsraad.nl/en/publications/health-basedreassessment-administrative-occupational-exposure-limitsthallium-and-wate

7. Cheam V, Garbai G, Lechner J, Rajkumar J. Local impacts of coal mines and power plants across Canada: I. Thallium in waters and sediments. Water Qual Res J Can 2000;35:581607.

8. Cheam V. Thallium contamination of water in Canada. Water Qual Res J Can 2001;36:851-77.

9. McConnell JR, Edwards R. Coal burning leaves toxic heavy metal legacy in the Arctic. PNAS 2008;34:12140-4.

10. Lin TS, Nriagu J. Thallium speciation in the Great Lakes. Environ Sci Technol 1999;33:3394-7.

11. Galván-Arzate S, Santamaría A. Thallium toxicity. Toxicol Lett 1998;99:1-13.

12. Frattini P. Thallium properties and behaviour - A Literature Study [displayed 23 April 2009]. Available at http://arkisto. gtk.fi/s41/S41_0000_2005_2.pdf.

13. Rehkämper M, Nielsen SG. The mass balance of dissolved thallium in the oceans. Mar Chem 2004;85:125-39.

14. National Research Council of Canada (NRCC). Data sheets on selected toxic elements. Ottawa $(\mathrm{ON})$ : Associate Committee on Scientific Criteria for Environmental Quality; 1982.
15. Leonard A, Gerberr GB. Mutagenicity, carcinogenicity and teratogenicity of thallium compounds. Mutat Res 1997;387:47-53.

16. Xiao T, Boyle D, Guha J, Rouleau A, Hong Y, Zheng B. Ground water related thallium transfer processes and their impact on the ecosystem: southwest Guizhou Province, China. Appl Geochem 2003;18:675-91.

17. Percival TJ, Radtke AS. Sedimentary-rock-hosted disseminated gold mineralization in the Alsar district, Macedonia. Can Mineral 1994;32:649-65.

18. Hofmann BA, Knill MD. Geochemistry and genesis of the Lengenbach $\mathrm{Pb}-\mathrm{Zn}$-As-Tl-Ba-mineralization, Binn Valley, Switzerland. Miner Depos 1996;31:319-39.

19. Krupp RE, Seward TM. The Rotokawa geothermal system, New Zealand: an active epithermal gold-depositing environment. Econ Geol Bull Soc 1987;82:1109-29.

20. Kabata-Pendias A, Pendias H. Trace Elements in Soils and Plants. $2^{\text {nd }}$ ed. Florida: CRC Press; 1992.

21. US Geological Survey, Mineral Commodity Summaries (2002) - Thallium [displayed 23 April 2009]. Available at http://minerals.usgs.gov/minerals/pubs/commodity/ thallium/840302.pdf.

22. Murao S, Itoh S. High thallium content in Kuroko-type ore. J Geochem Explor 1992;43:223-31.

23. US Environmental Protection Agency (US EPA). Technical Factsheet on: Thallium [displayed 23 April 2009]. Available at http://www.epa.gov/safewater/pdfs/factsheets/ioc/tech/ thallium.pdf

24. US Environmental Protection Agency (US EPA). Consumer Factsheet on: THALLIUM [displayed 23 April 2009]. Available at http://www.epa.gov/safewater/pdfs/factsheets/ ioc/thallium.pdf

25. Office of Environmental Health Hazard Assessment (OEHHA). Responses to comments on the technical support document public health goal for thallium in drinking water [displayed 23 April 2009]. Available at http://www.oehha. ca.gov/water/phg/pdf/thalirs.pdf.

26. Canadian Council of Ministers of the Environment (CCME). Summary of existing Canadian environmental quality guidelines (2003) [displayed 23 April 2009]. Available at http://ceqg-rcqe.ccme.ca/download/en/215/

27. Galván-Arzate S, Santamaría A. Thallium toxicity. Toxicol Lett 1998;99:1-13.

28. USGG Mineral Information. Thallium. Statistics and information. Mineral Commodity Summaries 2006 [displayed 23 April 2009]. Available at http://minerals.usgs. gov/minerals/pubs/commodity/thallium.

29. USGG Mineral Information. Thallium. Statistics and information. Mineral Commodity Summaries 2007 [displayed 23 April 2009]. Available at http://minerals.usgs. gov/minerals/pubs/commodity/thallium.

30. USGG Mineral Information. Thallium. Statistics and information. Mineral Commodity Summaries 2009 [displayed 23 April 2009]. Available at http://minerals.usgs. gov/minerals/pubs/commodity/thallium.

31. Britten JS, Blank M. Thallium activation of the $(\mathrm{Na}+/ \mathrm{K}+)-$ activated ATPase of rabbit kidney. Biochim Biophys Acta 1968;159:160-6.

32. World Health Organization (WHO). International Programme on Chemical Safety (IPCS). Thallium. Environmental health criteria. Vol. 182. Geneva: WHO; 1996. 
33. Ramsden D. Thallium. In: Waring RH, Steventon GB, Mitchell SC, editors. Molecules of Death. London: Imperial College Press; 2002. p. 304-11.

34. Mulkey JP, Oehme FW. A review of thallium toxicity. Vet Hum Toxicol 1993;35:445-53.

35. Villaverde MS, Verstraeten SV. Effects of thallium(I) and thallium(III) on liposome membrane physical properties. Arch Biochem Biophys 2003;417:235-43.

36. Hanzel CE, Villarverde MS, Verstraeten SV. Glutathione metabolism is impaired in vitro by thallium(III) hydroxide. Toxicology 2005;207:501-10.

37. Hanzel CE, Verstraeten SV. Thallium induces hydrogen peroxide generation by impairing mitochondrial function. Toxicol Appl Pharmacol 2006;216:485-92.

38. Halliwell B, Gutteridge JMC. Free Radicals in Biology and Medicine. $3^{\text {rd }}$ ed. London: Oxford University Press; 1999.

39. SM, Brailovskaya IV. $\mathrm{Tl}^{+}$increases the permeability of the inner membranes of rat liver mitochondria for monovalent cations. Dokl Biochem Biophys 2001;378:145-9.

40. Bragadin M, Toninello A, Bindoli A, Rigobello MP, Canton M. Thallium induces apoptosis in Jurkat cells. Ann NY Acad Sci 2003;1010:283-91

41. Korotkov SM, Lapin LV. Thallium induces opening of the mitochondrial permeability transition pore in the inner membrane of rat liver mitochondria. Dokl Biochem Biophys 2003;392:247-52.

42. Misra UK, Kalita J, Yadav RK, Ranjan P. Thallium poisoning: emphasis on early diagnosis and response to haemodialysis. Postgrad Med J 2003;79:103-5.

43. Hoffman RS. Thallium poisoning during pregnancy: a case report and comprehensive literature review. J Toxicol Clin Toxicol 2000;38:767-75.

44. Galván-Arzate $\mathrm{S}$, Ríos $\mathrm{C}$. Thallium distribution in organs and brain regions of developing rats. Toxicology 1994;90:63-9.

45. Galván-Arzate S, Martínez A, Medina E, Santamaría A, Ríos C. Subchronic administration of sublethal doses of thallium to rats: effects on distribution and lipid peroxidation in brain regions. Toxicol Lett 2000;116:37-43.

46. Moeschlin S. Thallium poisoning. Clin Toxicol 1980;17:13346.

47. Sabbioni E, Goetz L, Bignoli G.Health and environmental implications of trace metals released from coal-fired power plants: an assessment study of the situation in the European Community. Sci Total Environ 1984;40:141 -154.

48. Saddique A, Peterson CD. Thallium poisoning: a review. Vet Hum Toxicol 1983;25:16-22.

49. Kuo HC, Huang CC, Tsai YT. Acute painful neuropathy in thallium poisoning. Neurology 2005;65:302-4.

50. Jha S, Kumar R, Kumar R. Thallium poisoning presenting as paresthesias, paresis, psychosis and pain in abdomen. $\mathrm{J}$ Assoc Physicians India 2006;54:53-5.

51. Lu CI, Huang CC, Chang YC, Tsai YT, Kuo HC, Chuang YH, Shih TS. Short-term thallium intoxication. Arch Dermatol 2007;143:93-8

52. Saha A, Sadhu HG, Karnik AB, Patel TS, Sinha SN, Saiyed $\mathrm{HN}$. Erosion of nails following thallium poisoning: a case report. Occup Environ Med 2004;61:640-2.

53. Zhao G, Ding M, Zhang B, Lv W, Yin H, Zhang L, Ying Z, Zhang Q. Clinical manifestations and management of acute thallium poisoning. Eur Neurol 2008;60:292-7.

54. Thompson DF. Management of thallium poisoning. Clin Toxicol 1981;18:979-90

55. Thompson DF, Callen ED. Soluble or insoluble Prussian blue for radiocesium and thallium poisoning? Ann Pharmacother 2004;38:1509-14.

56. Hoffman RS. Thallium toxicity and the role of Prussian blue in therapy. Toxicol Rev 2003;22:29-40.

57. Shamshinova AM, Ivanina TA, Yakovlev AA, Shabalina LP, Spiridonova VS. Electroretinography in the diagnosis of thallium intoxication. J Hyg Epidemiol Microbiol Immunol 1990;34:113-21. 


\section{Sažetak}

\section{TOKSIČNOST TALIJA U HUMANOJ POPULACIJI}

Talij je u prirodi široko rasprostranjen teški metal, prisutan u vrlo niskim koncentracijama pa ga stoga ubrajamo u elemente u tragovima. Budući da organizmima nije potreban ni u jednoj razvojnoj fazi, ne ubrajamo ga u grupu esencijalnih elemenata. Talij zbog njegovih svojstava ubrajamo među najtoksičnije teške metale.

Povremeno se još uvijek pojavljuju slučajevi u kojima je talij upotrijebljen kao sredstvo za pokušaj ubojstva, odnosno samoubojstva, ali i slučajevi nenamjernog, slučajnog trovanja talijem. U današnje vrijeme potencijalna opasnost od trovanja talijem postoji zbog profesionalne izloženosti, izbijanja ekološke katastrofe ili zbog akumulacije u hranidbenim lancima, uglavnom zbog uzgoja hrane na onečišćenom tlu. Sve češća uporaba talija u visokotehnološkoj industriji kao odgovor na zahtjeve moderne tehnologije neprestano povećava rizik od izloženosti svih živih organizama štetnim utjecajima talija u okolišu.

Talij ima izuzetno negativan učinak na različite organske sustave, a osobito na živčani sustav. Mehanizmi toksičnosti talija još uvijek nisu u potpunosti razjašnjeni, premda važnu ulogu imaju poremećaji metabolizma glutationa, oksidativni stres i narušavanje homeostaze posredovane ionima kalija. Nedostatak podataka o mutagenim, kancerogenim ili teratogenim učincima talija i njegovih spojeva u ljudi opravdava buduća istraživanja ovog vrlo toksičnog metala.

KLJUČNE RIJEČI: alopecija, onečišćenje okoliša, periferna neuropatija, teški metal, trovanje

\section{CORRESPONDING AUTHOR:}

\section{Petra Cvjetko}

Department of Molecular Biology

Faculty of Science, University of Zagreb

Horvatovac 102 a, HR-10000 Zagreb

E-mail:pcvjetko@zg.biol.pmf.hr 